\title{
Pengembangan modul sistem operasi berbasis Contextual Teaching Learning (CTL) untuk menumbuhkan keaktifan belajar siswa di SMKN 1 Pogalan
}

\author{
Arif Nurnanto ${ }^{1}$, Setiadi Cahyono Putro², Hary Suswanto ${ }^{3}$ \\ 1. Universitas Negeri Malang, Indonesia | arifurnanto@gmail.com \\ 2. Universitas Negeri Malang, Indonesia | setiadicahyo@gmail.com \\ 3. Universitas Negeri Malang, Indonesia | hary.suswanto.ft@um.ac.id
}

\begin{abstract}
Abstrak
Tujuan dari pengembangan ini adalah untuk, membuat sebuah buku, mengobservasi keaktifan belajar siswa saat menggunakan buku yang dikembangkan dan mendeskripsikan hasil uji validasi buku untuk siswa SMKN 1 Pogalan Trenggalek. Tahap pengembangannya meliputi, (1) analisis kebutuhan; (2) perencanaan; (3) pengembangan produk awal; (4) validasi ahli; (5) uji coba kelompok kecil; (6) uji coba kelompok besar; (7) revisi; dan (8) diseminasi. peneliti juga melakukan observasi keaktifan menggunakan angket yang mengadopsi milik Sardiman. Peneliti juga melakukan uji terhadap responden mengenai isi dari materi yang ada pada buku.
\end{abstract}

Kata Kunci

Modul Pembelajaran, Sistem Operasi, CTL

TEKNO Volume 28 Issue 1 | Jurusan Teknik Elektro, Universitas Negeri Malang, Indonesia | Maret 2018

A. Nurnanto, S.C. Putro, H. Suswanto | Pengembangan modul sistem operasi berbasis Contextual... 


\section{TEKNO Junal Teknologi Eekkro dan Kejuruan}

http://journal2.um.ac.id/index.php/tekno | ISSN 1693-8739

\section{Pendahuluan}

Kurangnya media pembelajaran diindikasikan membuat siswa menjadi kurang aktif dalam belajar. Hal ini terbukti pada saat peneliti melakukan observasi pada salah satu Sekolah Menengah Kejuruan Negeri (SMKN) di Kabupaten Trenggalek dan siswa diindikasikan kurang aktif. Modul merupakan salah satu bentuk bahan ajar yang di kemas secara utuh dan sistematis, di dalamnya memuat seperangkat pengalaman belajar yang terencana dan didesain untuk membantu peserta didik menguasai tujuan belajar yang spesifik. (Daryanto, 2013: 9).

Pada saat observasi awal terdapat sejumlah alasan ketidak sesuaian modul yang tidak digunakan hal ini diperoleh dari wawancara yang peneliti lakukan dengan guru Sistem Operasi (SO) di SMKN 1 Pogalan. Hal ini disebabkan karena tidak sesuaian antara isi dan kemampuan sekolah dalam menyediakan sarana dan prasarana. Menurut Widoretno (2009) materi yang disajikan di dalam modul harus disajikan secara logis dan sistematis, sehingga siswa dapat mengetahui kapan memulai dan mengakhiri belajar suatu modul, serta tidak menimbulkan pertanyaan mengenai apa yang harus dilakukan atau dipelajari.

Penggunaan gambar atau foto yang ada pada buku diindikasikan akan memudahkan siswa dalam memahami isi dari sebuah pembahasan, demikian pula materi yang rumit harus dapat dijelaskan dengan cara yang sederhana, yang sesuai dengan tingkat berpikir siswa. Menurut Widoretno (2009) materi yang disajikan di dalam modul harus disajikan secara logis dan sistematis, sehingga siswa dapat mengetahui kapan memulai dan mengakhiri belajar suatu modul, serta tidak menimbulkan pertanyaan mengenai apa yang harus dilakukan atau dipelajari. Penggunaan bahan ajar yang menarik membuat siswa mampu menguasai materi yang diajarkan.

Penggunaan CTL tersebut diharapkan siswa menjadi lebih aktif dari sebelumnya. Diharapkan siswa mampu menggali kemampuan belajar dengan berinteraksi satu sama lain. Mengaitkan setiap materi dengan kehidupan sehari-hari akan membuat siswa mampu berpikir jernih dalam kegiatan belajar.

Berdasarkan Center for Occupational Research and Development (CORD) (dalam Suprijono, 2009:83) penerapan strategi pembelajaran CTL sebagai berikut: (a) Relating, belajar dikaitkan dengan konteks pengalaman kehidupan nyata; (b) Experiencing, belajar adalah kegiatan mengalami; (c) Appliying, belajar menekankan pada proses mendemonstrasikan pengetahuan yang dimiliki dalam konteks pemanfaatannya, (d) Cooperating, belajar merupakan proses kolaboratif dan kooperatif melalui belajar kelompok; (e) Transferring, belajar menekankan pada terwujudnya kemampuan memanfaatkan pengetahuan dalam situasi atau konteks baru.

Berdasarkan hasil observasi menyebutkan bahwa masih terdapat beberapa materi yang kurang sesuai dengan silabus maupun dengan media praktikum yang digunakan dan menggunakan sistem yang tidak cocok dengan media yang digunakan.

Media yang mampu mencakup seperangkat pengalaman belajar yang terencana dan di desain untuk membantu siswa dalam belajar. Menurut Widoretno (2009), penggunaan modul di dalam proses belajar dapat meningkatkan hasil belajar siswa berhubungan langsung dengan manfaat modul sebagai media pembelajaran

TEKNO Volume 28 Issue 1 | Jurusan Teknik Elektro, Universitas Negeri Malang, Indonesia | Maret 2018

A. Nurnanto, S.C. Putro, H. Suswanto | Pengembangan modul sistem operasi berbasis Contextual... 


\section{TEKNO Jumal Teknologi Elekrro dan Kejuruan}

http://journal2.um.ac.id/index.php/tekno | ISSN 1693-8739

Pengembangan modul Sistem Operasi berbasis CTL diharapkan dapat membuat siswa dapat aktif dalam belajar dan tidak merasa jenuh karena didukung dengan tulisan dan gambar yang menarik dan mudah dipahami. Serta dapat digunakan di mana saja. Pentingnya buku baru yang menunjang keaktifan siswa membuat peneliti membuat bahan ajar berbasis CTL. Penggunaan berbasis CTL diharapkan akan menumbuhkan keaktifan siswa.

\section{Metode}

Tahapan metode penelitian mengacu pada model pengembangan milik Sadiman. Tahapan pada Model Pengembangan milik Sadiman meliputi, (1) Identifikasi Masalah; (2) Perumusan Tujuan; (3) Perumusan butir-butir materi; (4) Perumusan pengukur keberhasilan; (5) Penulisan Naskah Media; (6) Tes/Uji Coba; (7) Revisi dan; (8) Siap Produksi.

Tahapan penelitian yang dilakukan yaitu, (1) Identifikasi Masalah (melakukan observasi awal ke sekolah), (2) Perumusan Tujuan (analisis tujuan), (3) Perumusan butir- butir materi, (4) Perumusan pengukur keberhasilan, (5) Penulisan Naskah Media, (6)Tes/Uji Coba (Uji coba dilakukan pada 3 aspek, (a) aspek media, (b) aspek materi, (c) aspek siswa,), (7) Revisi (revisi dilakukan jika respons negatif atau saran perbaikan dari aspek media kemudian diuji cobakan ke aspek materi lalu ke siswa) dan (8) Siap Produksi.

Pada penelitian pengembangan ini, validasi modul dilakukan dalam lima tahap. Pertama, yaitu penilaian validasi aspek media dan aspek materi yang dilakukan oleh ahli media dan ahli materi. Kedua, yaitu kelompok kecil yang terdiri dari 3 responden kelas XI SMKN 1 Pogalan. Tahap ketiga, yaitu uji coba kelompok besar yang terdiri dari 30 siswa kelas XI SMKN 1 Pogalan. Keempat, peneliti melakukan observasi keaktifan terhadap modul yang dikembangkan untuk mengetahui tujuan dari pengembangan modul yang dilakukan. Kelima, Peneliti melakukan uji kelayakan isi materi kepada 3 responden.

Responden pertama terdiri dari siswa kelas XI SMKN 1 Suruh. Responden kedua adalah siswa dari SMK Wahid Hasyim Trenggalek. Responden ketiga adalah SMKN 1 Pogalan. Peneliti memilih ketiga sekolah dengan mempertimbangkan semua kriteria sekolah dari yang marjinal sampai terdepan.

Responden pertama termasuk dalam kriteria sekolah yang menengah, terlihat dari akreditasi yang dimilikinya yaitu akreditasi B. Sedangkan pada Responden kedua merupakan kriteria sekolah marjinal (pinggiran), dapat dilihat dari akreditasinya yaitu belum ter- akreditasi. Responden ketiga merupakan sekolah dengan kriteria terdepan dapat dilihat dari akreditasinya yaitu akreditasi $A$.

Data yang dikumpulkan berupa data kuantitatif dan kualitatif. Data kuantitatif diperoleh dari hasil penilaian dan tanggapan oleh validator ahli dan sasaran pengguna. Sementara, data kualitatif diperoleh dari kritik, saran dan tanggapan yang diberikan oleh subjek uji coba. Instrumen pengumpulan data yang digunakan berupa angket yang bersifat tertutup.

TEKNO Volume 28 Issue 1 | Jurusan Teknik Elektro, Universitas Negeri Malang, Indonesia | Maret 2018

A. Nurnanto, S.C. Putro, H. Suswanto | Pengembangan modul sistem operasi berbasis Contextual... 


\section{TEKNO Jumal Teknologi Elekrto dan Kejuruan}

http://journal2.um.ac.id/index.php/tekno | ISSN 1693-8739

Aspek-aspek penilaian pada penilaian aspek media, materi dan siswa yang digunakan mengacu pada aspek-aspek penilaian yang dikembangkan oleh Nesbit dan Li (2007) yang dikenal dengan LORI (learning object review instrument) dan terdiri atas 9 aspek penilaian.

Sementara, teknik analisis data yang sesuai untuk menganalisis hasil angket adalah teknik analisis deskriptif dengan rata-rata scoring jawaban pada masing-masing item yang dinilai (Arikunto, 2006:239-243).

Tingkat kriteria validitas yang digunakan dalam penelitian pengem- bangan ini disajikan pada Tabel 1.

Tabel 1. Kriteria Validitas Kelayakan Media Berdasarkan Skor Angket

\begin{tabular}{lll}
\hline Skor (Rata-rata) & Tingkat Validitas & Keterangan \\
\hline $3,01-4,00$ & Tinggi & Layak, tidak perlu direvisi \\
$2,01-3,00$ & Sedang & Kurang layak, perlu direvisi \\
$1,00-2,00$ & Rendah & Tidak layak, revisi total
\end{tabular}

(Sumber: Arikunto, 2006)

Media pembelajaran yang dikembangkan dapat dikatakan berhasil dan sesuai dengan tingkat kriteria kelayakan apabila rata-rata skor yang didapat mencapai skor minimal 3,01 (kategori tinggi).

\section{Hasil}

Produk yang dikembangkan berupa buku. Adapun materi yang terdapat pada buku terdiri dari 6 bab, yaitu: (1) Perkembangan Sistem Operasi Open Source, (2) Struktur Sistem Operasi Open Source, (3) Proses Booting pada Sistem Operasi Open Source, (4) Instalasi Sistem Operasi Open Source, (5) Admin- istrasi Sistem Operasi Open Source dan, (6) Prosedur Pencarian Kesalahan pada Sistem Operasi Open Source.

Adapun sampul dan isi sebagai berikut: 


\section{TEKNO Junal Teknologi Elektro dan Kejuruan}

http://journal2.um.ac.id/index.php/tekno | ISSN 1693-8739



Gambar 1. Tampilan Sampul Depan

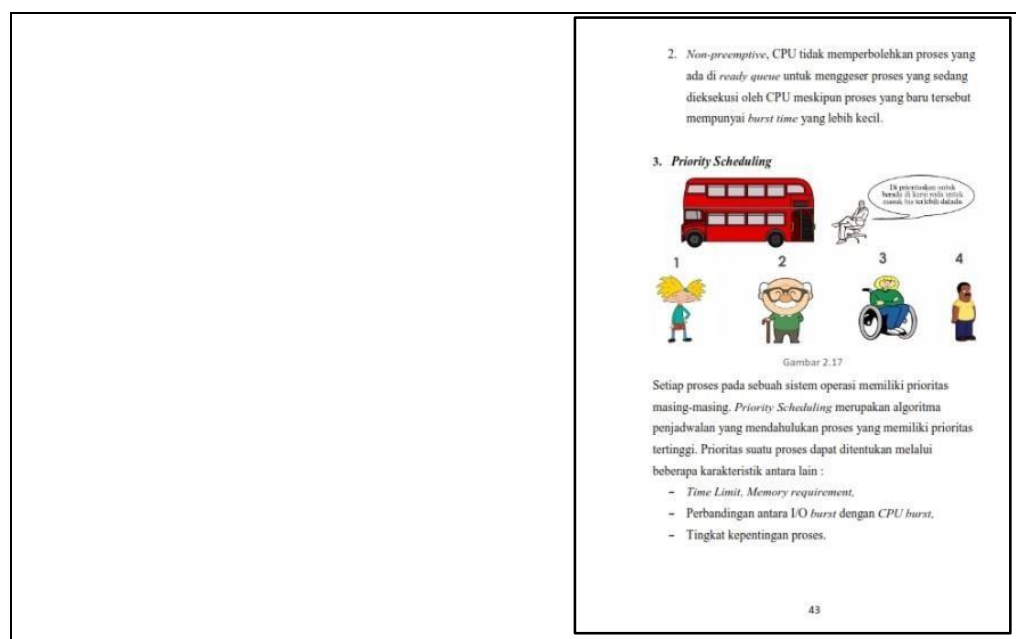

Gambar 2. Tampilan halaman yang terdapat unsur CTL 


\section{TEKNO Junal Teknologi Eektro dan Kejuruon}

http://journal2.um.ac.id/index.php/tekno | ISSN 1693-8739

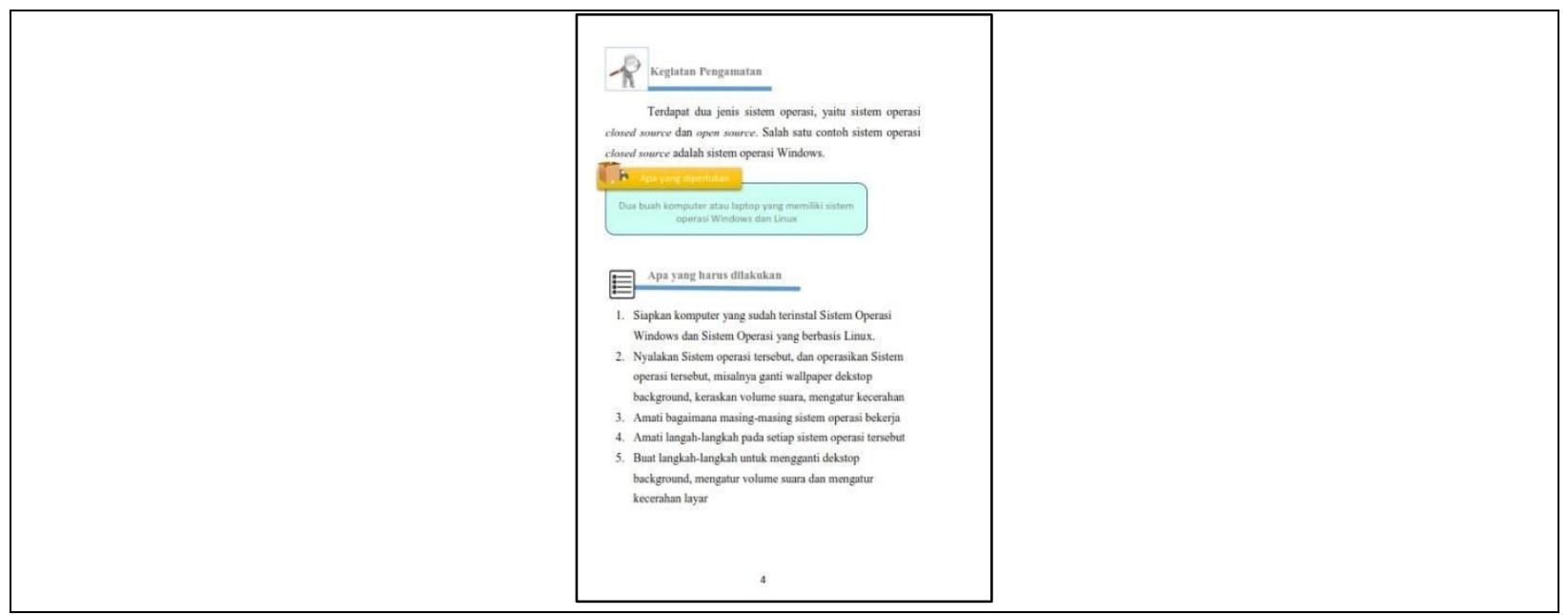

Gambar 3. Tampilan Kegiatan Pengamatan (1)

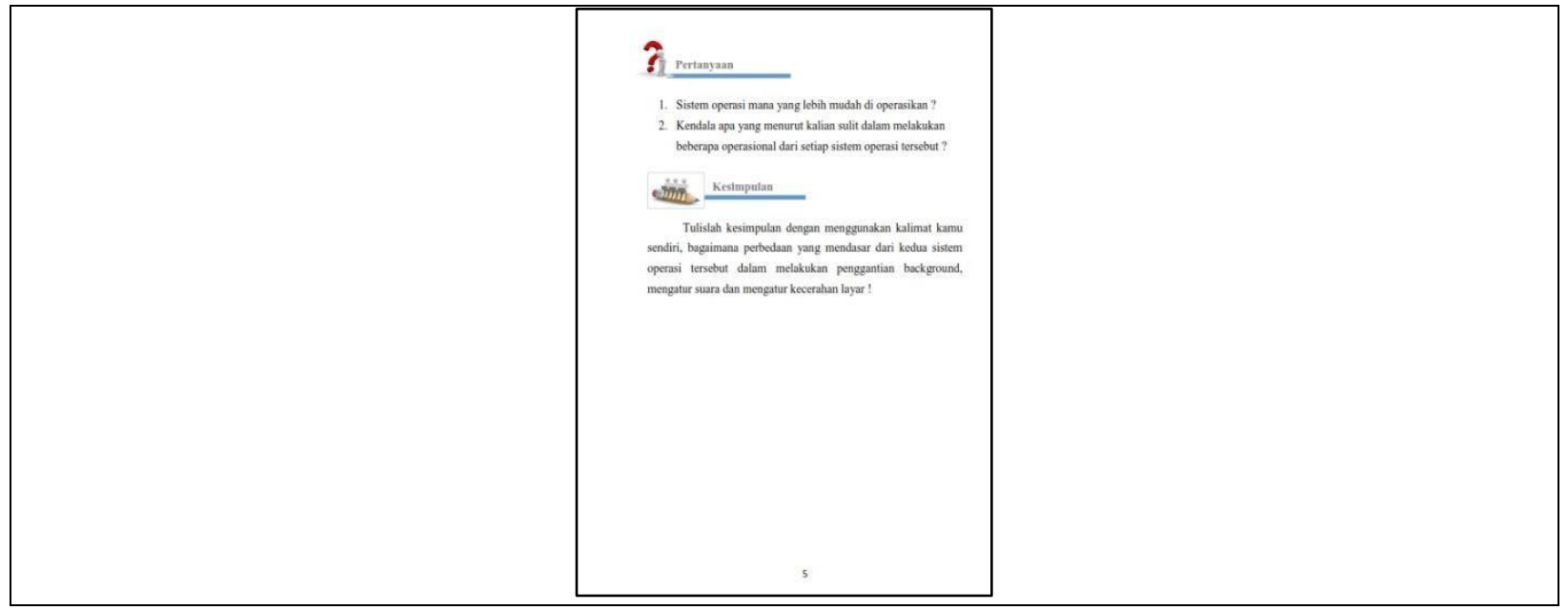

Gambar 4. Tampilan Kegiatan Pengamatan (2)

Data hasil penilaian pada tiap aspek yang dinilai, dapat dilihat pada Tabel 2.

Tabel 2. Perolehan Skor Penilaian Tiap Aspek (Rata-rata)

\begin{tabular}{llllll}
\hline No. & Aspek yang Dinilai & Ahli Media & $\begin{array}{l}\text { Ahli } \\
\text { Materi }\end{array}$ & Kelompok Kecil & Kelompok Besar \\
\hline 1 & Content Quality & 4 & 3,2 & 3,2 & 3,2 \\
2 & Learning Goal Alignment & 3 & 3,25 & 3,16 & 3,24 \\
3 & Feedback And Adaption & 3,33 & 3 & 3,33 & 3,27 \\
4 & Moivation & 3,5 & 3,33 & 3,44 & 3,54 \\
5 & Presentation Design & 3,71 & 3,25 & 3,55 & 3,42 \\
6 & Usability & 4 & 3,5 & 3 & 3,64 \\
7 & Accessibility & 3 & 3 & 3,5 & \\
\hline
\end{tabular}

TEKNO Volume 28 Issue 1 | Jurusan Teknik Elektro, Universitas Negeri Malang, Indonesia | Maret 2018

A. Nurnanto, S.C. Putro, H. Suswanto | Pengembangan modul sistem operasi berbasis Contextual... 


\section{TEKNO Junal Teknologi Elektro dan Kejuruan}

http://journal2.um.ac.id/index.php/tekno | ISSN 1693-8739

Sedangkan hasil perolehan rata-rata skor dari uji coba secara keseluruhan disajikan pada Tabel 3.

Tabel 3. Hasil Perolehan Skor Uji Coba Secara Keseluruhan

\begin{tabular}{lllll}
\hline No. & Subyek & Total Skor & Rata-rata & Keterangan \\
\hline 1 & Ahli Media & 83 & 3,61 & Layak Digunakan \\
2 & Ahli Materi & 96 & 3,20 & Layak Digunakan \\
3 & Kelompok Kecil & 224 & 3,39 & Layak Digunakan \\
4 & Kelompok Besar & 2697 & 3,50 & Layak Digunakan \\
\hline
\end{tabular}

Hasil dari observasi keaktifan menyatakan siswa aktif terlihat dari tabel berikut:

Tabel 4. Hasil Perolehan Skor Uji Coba

\begin{tabular}{lllll}
\hline No. & Subyek & Aspek 1 & Aspek 2 & Aspek 3 \\
\hline 1 & Observer 1 & 3 & 4 & 4 \\
2 & Observer 2 & 4 & 4 & 4 \\
3 & Observer 3 & 4 & 4 & 4 \\
4 & Observer 4 & 4 & 4 & 4 \\
\hline
\end{tabular}

Tabel 5. Hasil Perolehan Skor Uji Coba Responden

\begin{tabular}{llll}
\hline No & Subyek & Jumlah & Rata-rata \\
\hline 1 & Responden 1 & 6960 & 3,21 \\
2 & Responden 2 & 4265 & 3,43 \\
3 & Responden 3 & 7539 & 3,47 \\
\hline
\end{tabular}

\section{Pembahasan}

Materi dikembangkan dengan memperhatikan unsur CTL dan dikemas menjadi lebih padat. Adanya unsur kontekstual diharapkan dapat menumbuhkan keaktifan belajar siswa dalam belajar. Modul yang dikembangkan terdapat beberapa tambahan seperti kegiatan pengamatan dan kotak yang berisi sepenggal kalimat dari materi yang dihubungkan dengan kehidupan nyata. Kegiatan pengamatan bertujuan untuk menstimulasi siswa supaya aktif dalam belajar khususnya pada bidang keterampilan.

Keseluruhan validasi dan uji coba yang telah dilaksanakan menyatakan bahwa media pembelajaran yang dikembangkan termasuk dalam kategori valid atau layak untuk digunakan dalam pembelajaran. Hal ini dibuktikan dari hasil validasi oleh ahli media dan ahli materi berupa rata-rata penilaian skor angket yang diperoleh melebihi harapan minimal yaitu di atas 3,01. Sedangkan pada uji coba kelompok kecil dan kelompok besar menyatakan bahwa media pembelajaran yang dikembangkan juga termasuk dalam kategori layak digunakan dengan peningkatan hasil rata-rata skoring antara uji coba kelompok kecil dan kelompok besar sebesar 0,11 poin setelah dilakukan revisi.

TEKNO Volume 28 Issue 1 | Jurusan Teknik Elektro, Universitas Negeri Malang, Indonesia | Maret 2018

A. Nurnanto, S.C. Putro, H. Suswanto | Pengembangan modul sistem operasi berbasis Contextual... 


\section{TEKNO Jumal Teknologi Elekrto dan Kejuruan}

http://journal2.um.ac.id/index.php/tekno | ISSN 1693-8739

Pada observasi keaktifan, observer memegang 9 siswa dan ada yang memegang 8 siswa untuk diobservasi. Pada aspek pertama observer 1 cenderung memilih kriteria 3 dan observer lain cenderung memilih 4. Pada aspek 2 para observer cenderung memilih kriteria 4 dan pada aspek 3 para observer cenderung memilih kriteria 4. Sehingga dapat diambil kesimpulan buku yang dikembangkan mampu menumbuhkan keaktifan dalam belajar.

Pada uji responden, peneliti memilih 3 responden dengan kriteria dan latar belakang yang berbeda. Kriteria tersebut merupakan kriteria sekolah marjinal, menengah dan terdepan, pemilihan tersebut untuk melihat seberapa layaknya modul yang dikembangkan dapat digunakan.

\section{Kesimpulan}

Produk yang dihasilkan dari penelitian ini adalah buku yang dikembangkan dengan berbasis Contextual Teaching Learning(CTL). Buku yang dikembangkan merupakan buku yang berfungsi untuk mendukung kegiatan belajar mengajar. Materi yang disajikan pada buku yang dikembangkan merupakan materi- materi mata pelajaran Sistem Operasi pada semester 1.

Materi dikembangkan dalam bentuk yang sederhana. Selain penyajian materi, di dalam buku terdapat kegiatan pengamatan untuk menstimulasi siswa untuk aktif dalam belajar. Terdapat kotak untuk menggambarkan materi yang sedang dibahas dengan kegiatan yang ada pada kehidupan nyata dengan harapan dapat menumbuhkan keaktifan siswa dalam belajar.

Hasil dari validasi dari para ahli menyatakan bahwa media pembelajaran yang berupa buku termasuk dalam kategori valid atau layak untuk digunakan dalam pembelajaran dengan peningkatan hasil skoring antara uji coba kelompok kecil dan kelompok besar sebesar 0,11 poin setelah dilakukan revisi. Berdasarkan analisis data tiap aspek yang telah dijelaskan pada bab sebelumnya, buku yang dikembangkan telah memenuhi kriteria media pembelajaran yang baik menurut aspek penilaian LORI versi 1.5 (Nesbit, 2007) dengan kriteria validitas tinggi cenderung sedang pada setiap aspek.

Setelah dilakukan uji kelayakan media, peneliti melakukan observasi keaktifan, dari hasil observasi yang dilakukan oleh empat observer menunjukkan bahwa buku yang dikembangkan mampu menumbuhkan keaktifan belajar pada siswa. Setelah dilakukan observasi keaktifan, peneliti melakukan uji kelayakan isi kepada responden pada 3 sekolah, dengan memperhatikan kriteria sekolah yang berbeda.

Adapun saran dan masukan dari para ahli digunakan untuk perbaikan sebelum diuji cobakan kepada siswa. Sedangkan saran dan masukan dari siswa merupakan data kualitatif yang digunakan untuk revisi produk akhir sebelum dilakukan implementasi di lapangan ketika produk benar- benar digunakan.

Untuk pemanfaatannya, diharapkan siswa membaca terlebih da- hulu tujuan pembelajaran dalam setiap materi yang akan dipelajari. Siswa juga diharapkan membaca kalimat perumpamaan yang terdapat pada setiap kotak yang berisi gambar, karena di dalamnya

TEKNO Volume 28 Issue 1 | Jurusan Teknik Elektro, Universitas Negeri Malang, Indonesia | Maret 2018

A. Nurnanto, S.C. Putro, H. Suswanto | Pengembangan modul sistem operasi berbasis Contextual... 


\section{TEKNO Jumal Teknologi Elekrro dan Kejuruan}

http://journal2.um.ac.id/index.php/tekno | ISSN 1693-8739

mengandung unsur kontekstual. Serta siswa mampu mempraktikkan kegiatan pengamatan yang terdapat pada buku.

Dalam skala yang lebih luas, penggunaan buku dapat dijadikan se- bagai media pembelajaran alternatif dalam kegiatan pembelajaran. Buku dapat digunakan dalam skala luas ka- rena peneliti telah melakukan uji kelayakan isi materi ke 3 sekolah dengan kriteria sekolah yang berbeda. Buku dapat dijadikan media pembelajaran alternatif karena pada awalnya buku ini dikembangkan untuk mengatasi masalah di SMKN 1 Pogalan dalam upaya menumbuhkan keaktifan belajar siswa kelas $\mathrm{X}$.

Buku yang dikembangkan masih berfokus pada mata pelajaran Sistem Operasi kelas $\mathrm{X}$ jurusan TKJ semester 2. Untuk pengembangan lebih lanjut diharapkan dapat menam- bahkan materi Sistem Operasi pada semester 1.

Buku yang dikembangkan terdiri dari unsur teks dan gambar serta terdapat beberapa kegiatan pengamatan yang dapat dipraktikkan oleh siswa supaya mampu menumbuhkan keaktifan siswa dalam belajar. Sebagai saran untuk pengembangan lebih lanjut agar dapatnya unsur dan kegiatan pengamatan dikemas lebih baik lagi, jika dimungkinkan untuk pengembangannya agar menambahkan unsur lain yang bisa menjadikan buku ini lebih baik dan efektif.

\section{Daftar Rujukan}

Arikunto, S. 2013. Prosedur Penelitian (Suatu Pendekatan Praktik). Jakarta: Rinek Cipta.

Daryanto. 2013. Menyusun Modul (Bahan Ajar untuk Persiapan Guru dalam Mengajar). Yogyakarta: Gava Media.

Johnson, E. B. 2014. Contextual Teaching and Learning: Menjadikan Kegiatan Belajar- mengajar Mengasyikkan dan Bermakna. Bandung: Penerbit Kaifa.

Majid, A. 2012. perencanaan Pembelajaran (Mengembangkan Standar Kompetensi Guru). Bandung: Remaja Rosdakarya.

Sadiman, A. Dkk. 2009. Media Pendidikan: Pengertian, Pengembangan dan Pemanfaatannya. Jakarta: Rajawali Pers.

Nasution, S. 2010. Berbagai Pendekatan Dalam Proses Belajar Mengajar. Jakarta: Bumi Aksara. Rusman. 2012. Model-model Pembelajaran: Mengembangkan Profesionalisme Guru. Jakarta: Rajawali Pers.

Sadiman, A. Dkk. 2009. Media Pendidikan: Pengertian, Pengembangan dan Pemanfaatannya. Jakarta: Rajawali Pers.

Sugiyono. 2011. Metode Penelitian Kuantitatif, Kualitatif, dan R\&D. Bandung: Alfabeta.

Taniredja, T., dkk. 2013. Model-model Pembelajaran Inovatif dan Efektif. Bandung: Alfabeta. Universitas Negeri Malang. 2010.

Pedoman Penulisan Karya Ilmiah: Skripsi, Tesis, Disertasi, Artikel, Makalah, Tugas Akhir, Laporan Penelitian (Edisi Kelima). Malang: Universitas Negeri Malang.

TEKNO Volume 28 Issue 1 | Jurusan Teknik Elektro, Universitas Negeri Malang, Indonesia | Maret 2018 A. Nurnanto, S.C. Putro, H. Suswanto | Pengembangan modul sistem operasi berbasis Contextual... 


\section{TEKNO Jumal Teknologi Elekrto dan Kejuruan}

http://journal2.um.ac.id/index.php/tekno | ISSN 1693-8739

Widoretno, S. 2009. Penggunaan Masalah Dalam Modul Praktikum Sebagai Penuntun Kegiatan Lapangan Pada Matakuliah Ekologi Tumbuhan Surakarta: 2009

Suryoso, dan Nurohmanm, S. (2014).

Pengembangan Modul Elektronik berbasis WEB sebagai Media Pembelajaran Fisika. Jurnal Kependidikan, 44, 73-82. 